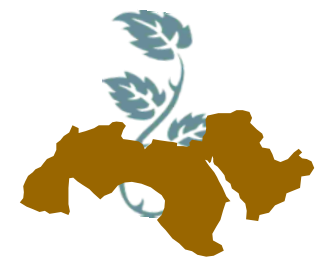

\title{
REMOVAL OF ALIZARIN RED S FROM AQUEOUS SOLUTION USING SODIUM BENTONITE
}

\author{
Eman A. El-Menofy, Omnia I. Ali and Kandil A.H.T. \\ Chemistry Dept., Fac. of Sci., Helwan Univ., Cairo, Egypt
}

Keywords: Removal, Alizarin red S (ARS), Bentonite

\section{ABSTRACT}

In this work, sodium bentonite (Bn) was used for removal of alizarin red $S$ (ARS) from aqueous solution using batch technique. Fourier transform infrared spectroscopy and X-ray diffraction were used to characterize sodium bentonite. Different parameters that would affect ARS dye removal such as initial $\mathrm{pH}$, contact time, initial ARS dye concentration, bentonite dose, and temperature were explored. The realized data from kinetic studies demonstrated the high fitness of pseudosecond-order kinetic model for better interpretation of the experimental data. The adsorption isotherms studies showed that Freundlich isotherm had a high correlation coefficient among the studied isotherm models. Thermodynamic studies proposed that ARS adsorption onto $\mathrm{Bn}$ was spontaneous in nature at the lower temperatures and exothermic.

\section{INTRODUCTION}

Dyes usually accumulate from the effluents discharged by various industries such as textiles, paper, cosmetics, rubber, and plastics [1, 2]. Dyes are poisonous to organisms and carcinogenic. Manufacturing wastewater having such dyes discharged into receiving water has become a serious environmental problem. One of the major environmental problems is the color removal from textile wastewater because of the difficulty of treating such water by traditional treatment methods [3]. ARS is used for coloring textile such as cotton, wool, and woven fabrics. ARS is an anionic anthraquinone dye and is highly durable and difficult to degrade because of its complex structure. In addition, it is known to possess carcinogenic properties and causes environmental problems [4].
Numerous techniques, such as chemical oxidation, flocculation, precipitation, membrane filtration, biodegradation and electrochemical techniques have been employed for dyes removal. The previously mentioned procedures have several drawbacks such as high cost, generation of secondary contaminants and low removal effectiveness. Adsorption has been shown high efficiency and be an economical process for the dyes removal from wastewater [5]. Currently activated carbons [6, 7] and resins [8] are commonly applied for the removal of dyes; however they are still expensive for practical application. Hence, searching for naturaloccurring materials and low cost adsorbent materials for dyes removal seems to be more significant. $\mathrm{Bn}$ clay is a kind of aluminosilicate clay and is mostly composed of montmorillonite that is characterized by one aluminum octahedral layer placed between two silicon tetrahedral layers. This clay is preferred due to its chemical and mechanical stability, high surface area, layered structure, low cost, abundant in most soils and high cation exchange capacity. Bn has a diversity of uses since it becomes a colloidal when mixed with water, swelling in water, and high plasticity. From its developed application is used as a dispersive agent. Bn clay also used as an industrial raw material in catalytic, rheological and sorptive applications. Moreover, it is used in some applications in industry, such as in drilling fluids, paper, cement, pharmaceutical field, dyes and ceramics. Bn has a layer structure, which gives the clay a good ion exchange capacity that is mostly responsible for relatively high viscosity. Bn has been extensively used in the extraction, and separation of a variety of inorganic and organic substances [9-16].

The purpose of this search was to evaluate the potential of $\mathrm{Bn}$ to remove ARS from aqueous solution and to determine the several factors that effect on its removal using $\mathrm{Bn}$, such as initial $\mathrm{pH}$, contact 
time, initial ARS dye concentration, bentonite mass, and temperature. As well as the kinetics, isotherms, and thermodynamic parameters of ARS removal from aqueous solution are investigated.

\section{Experimental}

\subsection{Materials}

Bentonite clay, sodium form was purchased from Thermofisher, Germany. Alizarin red $S$ was purchased from Riedel-de Häen AG, Germany. Chemical structure of the dye is shown in Fig. 1. Sodium hydroxide and hydrochloric acid (EI Nasr Pharmaceutical Chemicals Co.) were used for initial $\mathrm{pH}$ adjustment. A stock solution containing 500 $\mathrm{mg} \mathrm{L}^{-1}$ ARS was prepared by dissolving the required amount in distilled water. The desired concentrations of solutions in further experiments were obtained by successive dilutions. Distilled water is used throughout the work. All other chemicals and reagents used in this work were of analytical grade.<smiles>O=C1c2ccccc2C(=O)c2c1cc(S(=O)(=O)O)c(O)c2O</smiles>

Fig. 1. Chemical structure of ARS

\subsection{Instrumentation}

The spectrophotometric measurements are performed using a UV-Vis double-beam spectrophotometer (V-630 Jasco, Japan). A Jenco 6173 $\mathrm{pH}$-meter is used for $\mathrm{pH}$ measurements. Water bath shaker is used for shaking during experiments. FTIR spectra are recorded on a FTIR spectrometer (FT-IR-6100 Jasco, Japan), using $\mathrm{KBr}$ pellets in the range of $4000-400 \mathrm{~cm}^{-1}$ at room temperature with spectral resolution $4 \mathrm{~cm}^{-1}$. X-ray diffraction analysis is carried out using an X-ray diffractometer (Brucker D8Advanced, Germany) with $\mathrm{Cu} \mathrm{Ka}$ radiation $(\lambda=0.15406 \mathrm{~nm})$ in the $2 \theta$ range of $2^{\circ}$ to $70^{\circ}$.

\subsection{Adsorption studies}

Adsorption experiments were carried out using batch technique. To study the effect of $\mathrm{pH}$ on the adsorption process, $0.05 \mathrm{~g}$ of the adsorbent is mixed with $25 \mathrm{~mL}$ of ARS solution with initial concentration of $100 \mathrm{mg} \mathrm{L}^{-1}$. The initial $\mathrm{pH}$ is adjusted in the range of $2-10$ using drops of $0.1 \mathrm{M} \mathrm{HCl}$ and $0.1 \mathrm{M} \mathrm{NaOH}$. For adsorption kinetics studies, 25 $\mathrm{mL}$ of the ARS solution with initial concentration of $100 \mathrm{mg} \mathrm{L}^{-1}$ at $\mathrm{pH} 4$ is added to $0.05 \mathrm{~g}$ of adsorbent. In the adsorption isotherm studies, $0.05 \mathrm{~g}$ of the adsorbent is added to $25 \mathrm{~mL}$ of the ARS solutions with an initial concentration of 25, 50, 100, 200 and $400 \mathrm{mg} \mathrm{L}^{-1}$ at the $\mathrm{pH} 4$. In the thermodynamic studies, $0.05 \mathrm{~g}$ of the adsorbent is added to $25 \mathrm{~mL}$ of ARS solution with initial concentration $100 \mathrm{mg} \mathrm{L}^{-1}$ at different temperatures. After equilibration, the mixtures are centrifuged and the concentration of the ARS is determined spectrophotometrically using UV-Vis spectrophotometer at a wavelength of $420 \mathrm{~nm}$. The percentage of adsorption $(\% E)$ and $q_{\mathrm{e}}\left(\mathrm{mg} \mathrm{g}^{-1}\right)$ are calculated as follows:

$\%=\frac{\left(C_{i}-C_{e}\right)}{C_{i}} * 100$
$q_{\mathrm{e}}=\frac{\left(C_{i}-C_{e}\right) V}{m}$

where: $C_{i}$ is the initial dye concentration $\left(\mathrm{mg} \mathrm{L}^{-1}\right)$, $C_{e}$ is the equilibrium dye concentration $\left(\mathrm{mg} \mathrm{L}^{-1}\right), V$ is the volume of ARS used (L), and $m$ is the mass of adsorbent used (g).

\section{RESULTS AND DISCUSSION}

\subsection{Characterization}

\subsubsection{Fourier Transform Infrared (FTIR) Spec- troscopy}

FTIR spectra of $\mathrm{Bn}$ are recorded in the range of $4000-400 \mathrm{~cm}^{-1}$. The FTIR spectra of Bn are illustrated in Fig. 2. Peaks that observed at 3446.2 and $3622 \mathrm{~cm}^{-1}$ are due to the vibrations of inner $\mathrm{H}_{2} \mathrm{O}$ and hydroxyl groups of $\mathrm{Bn}$, respectively. The two peaks at 3237 and $1645 \mathrm{~cm}^{-1}$ are resulted from $\mathrm{H}_{2} \mathrm{O}$ bending and that appeared at $521.7 \mathrm{~cm}^{-1}$ and $462.8 \mathrm{~cm}^{-1}$ are attributed to Al-O-Si bending and Si- $\mathrm{O}$-Si bending, respectively. The peak at $622.895 \mathrm{~cm}^{-1}$ is related to the $\mathrm{Al}-\mathrm{O}$ and $\mathrm{Si}-\mathrm{O}$ 
out-of-plane vibration. In addition, the peak appeared at $922.8 \mathrm{~cm}^{-1}$ caused from Al-OH-Al bending [17].

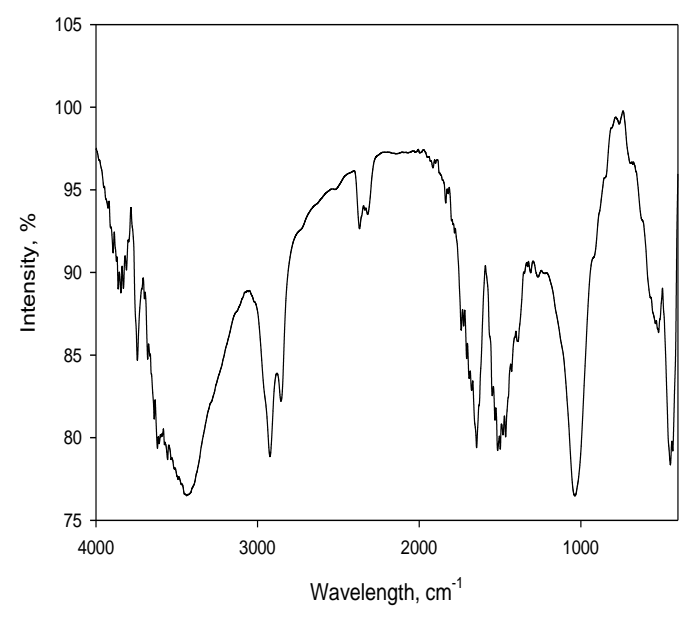

Fig. 2. FTIR spectra of $\mathrm{Bn}$.

\subsubsection{X-ray diffraction (XRD)}

The XRD obtained for $\mathrm{Bn}$ is shown in Fig. 3. The pattern that found for Bn showed the presence of montmorillonite $\left(7.07^{\circ}\right.$ and $\left.19.78^{\circ}\right)$ as a majority phase [18].

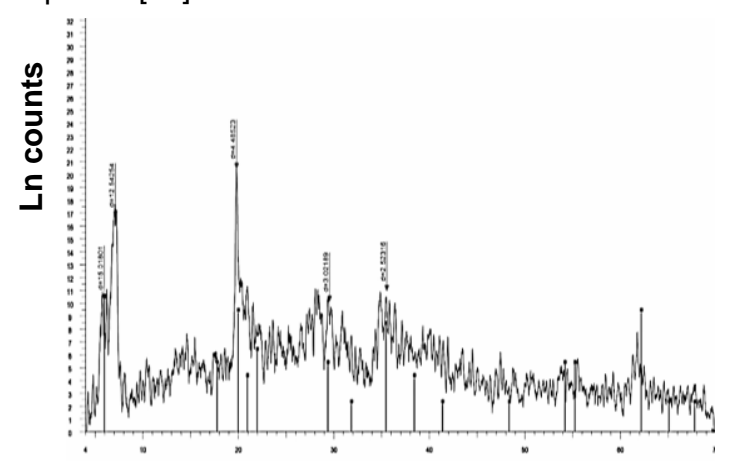

\section{2-theta}

Fig. 3. X-ray diffraction pattern for $\mathrm{Bn}$.

\subsection{Adsorption studies}

\subsubsection{Effect of initial pH}

The effect of initial $\mathrm{pH}$ on the removal of ARS using Bn from 2-10 is studied and the results are shown in Fig. 4. The maximum removal of ARS using $\mathrm{Bn}$ is achieved at $\mathrm{pH} 4$, then the removal percentage decreased as $\mathrm{pH}$ increased. At $\mathrm{pH}$ less than $\mathrm{pk}_{\mathrm{a}}$ of ARS, there is an electrostatic attraction between the cationic form of ARS molecules and the negatively charged surface of $\mathrm{Bn}$. As the $\mathrm{pH}$ increase; there is an electrostatic repulsion between the anionic form of ARS molecules and $\mathrm{Bn}$ resulting in decreasing the removal percentage of ARS.

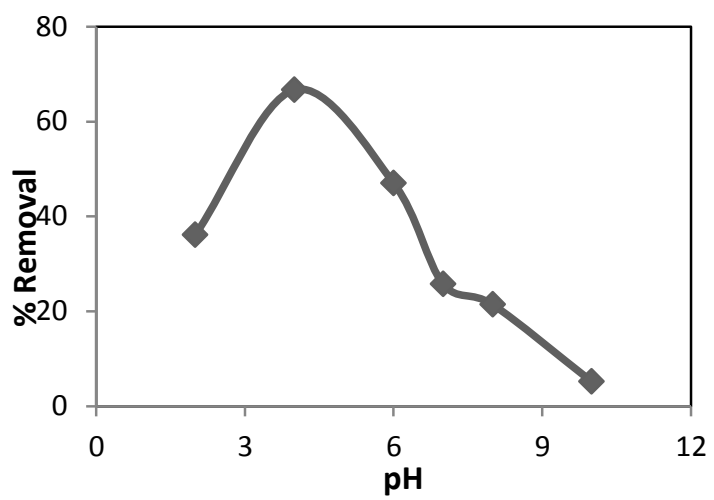

Fig. 4. Effect of initial $\mathrm{pH}$ on ARS removal using Bn.

\subsubsection{Effect of contact time}

The contact time is a significant parameter that used to optimize the processing period. The removal of ARS using $\mathrm{Bn}$ is investigated as a function of contact time and it is done in the range from 5 to $120 \mathrm{~min}$. From the results that are shown in Fig. 5, it can be concluded that 60 min is the optimum equilibrium contact time for ARS removal by $\mathrm{Bn}$.

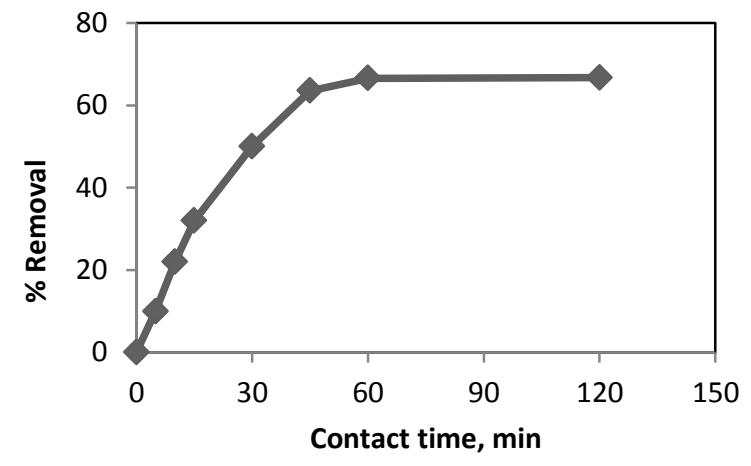

Fig. 5 Effect of contact time on ARS removal using Bn.

\subsubsection{Effect of adsorbent mass}

Fig. 6 shows the removal percentage of ARS using $\mathrm{Bn}$. The results indicated that the removal \% 
increase with increasing adsorbent dose from 0.01 to $0.2 \mathrm{~g}$. The increase in the adsorption efficiency of ARS can be attributed to a large total surface area of $\mathrm{Bn}$ and the accessibility of large number of adsorption sites [19, 20]. At $\mathrm{Bn}$ dosage that is higher than $0.05 \mathrm{~g}$, the concentration of the ARS on $\mathrm{Bn}$ surface is in equilibrium with the ARS concentration in solution [21].

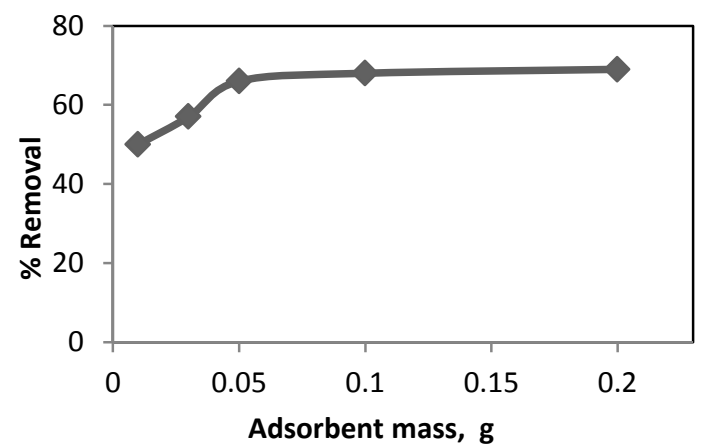

Fig. 6. Effect of adsorbent mass on ARS removal using Bn.

\subsubsection{Effect of ARS initial concentration}

The effect of ARS initial concentration on its removal using $\mathrm{Bn}$ is studied and the results are shown in Fig. 7. The $\mathrm{Bn}$ and dye solution of different initial concentrations of 10 to $400 \mathrm{mg} \mathrm{L}^{-1}$ are contacted for $60 \mathrm{~min}$ at $\mathrm{pH} 4$ with an adsorbent dose of $0.05 \mathrm{~g}$. The adsorption capacity of ARS increased from 4.25 to $122.15 \mathrm{mg} \mathrm{g}^{-1}$ by increasing the initial ARS dye concentration from 10 to 400 $\mathrm{mg} \mathrm{L}^{-1}$. This indicates that the ARS adsorption on $\mathrm{Bn}$ is concentration dependent [22].

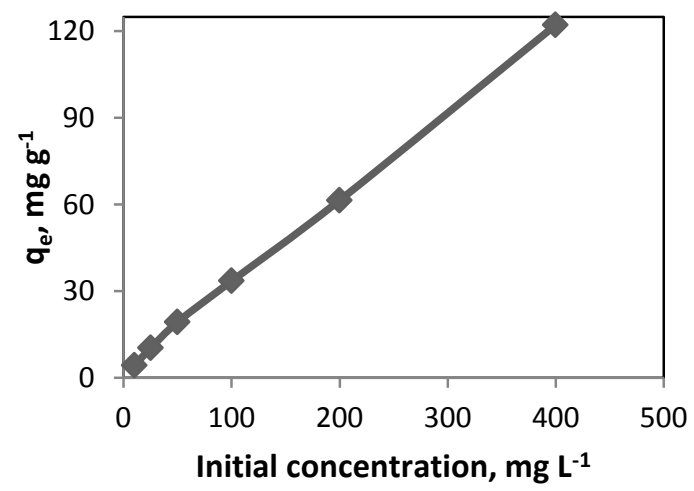

Fig. 7. Effect initial concentration of ARS on its removal using $\mathrm{Bn}$.

\subsubsection{Effect of temperature}

The study of the adsorption process of ARS onto $\mathrm{Bn}$ at different temperatures $(30,40,50$, and $60 \stackrel{\circ}{\circ}$ ) at $\mathrm{pH} 4$ using $0.05 \mathrm{~g}$ of $\mathrm{Bn}$ for 60 min was revealed in Fig. 8. The removal percentage decreased as the temperature increased. The obtained results indicated the exothermic nature of ARS adsorption onto Bn.

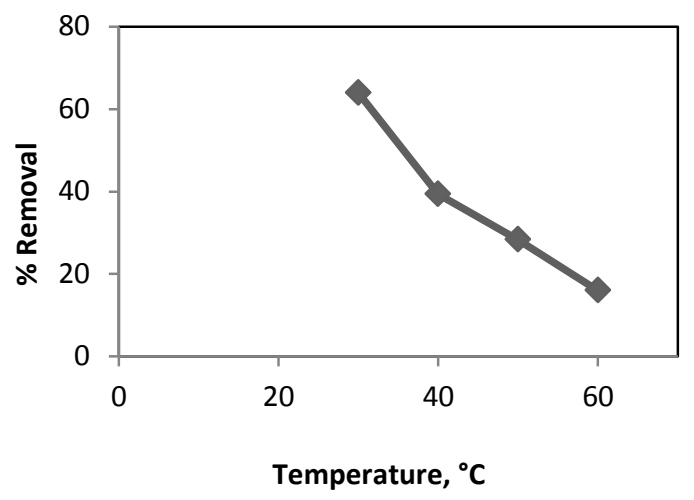

Fig. 8. Effect of temperature on removal of ARS using $\mathrm{Bn}$.

\subsection{Isotherm Studies}

Langmuir [23] and Freundlich [24] models are used to analyze the equilibrium isotherm adsorption data:

\section{Langmuir isotherm}

Langmuir isotherm model presume a monolayer for adsorption onto the surface of adsorbent with a definite amount of identical sites. Once an active site is occupied, no additional adsorption can occur at that site and Langmuir model is given by:

$\frac{C_{e}}{q_{e}}=\frac{1}{K_{L} q_{\max }}+\frac{C_{e}}{q_{\max }}$

Where: $C_{e}$ and $q_{e}$ are the equilibrium concentration of $A R S\left(\mathrm{mg} \mathrm{L}^{-1}\right)$, and the quantity of ARS adsorbed per unit mass of $\mathrm{Bn}$ at equilibrium concentration ( $\mathrm{mg} \mathrm{g}^{-1}$ ), respectively. $q_{\max }$ is the full monolayer adsorption ( $\mathrm{mg} \mathrm{g}^{-1}$ ) and $K_{L}$ is the Langmuir constant related to the affinity of $\mathrm{Bn}$ binding sites $\left(\mathrm{L} \mathrm{mg}^{-1}\right)$ and the these parameters values are registered in Table 1. 
Freundlich model

Freundlich model is based on a multilayer for adsorption on a heterogeneous surface and is set by:

$$
\ln q_{e}=\frac{1}{n} \ln C_{e}+\ln K_{F}
$$

Where: $n$ and $K_{F}$ are Freundlich constants indicating the intensity and adsorption capacity, respectively. The values of $n$ and $K_{F}$ are calculated from the slope and intercept of the plot of In $q_{\mathrm{e}}$ versus $\ln C_{e}$ and they are presented in Figure 9 and recorded in Table 1. From the magnitudes of the correlation coefficients values for the two models, the Freundlich model isotherm has better $R^{2}$ value than the other isotherm model (Table 1). This recommends that the ARS adsorption onto $\mathrm{Bn}$ is a physical process.

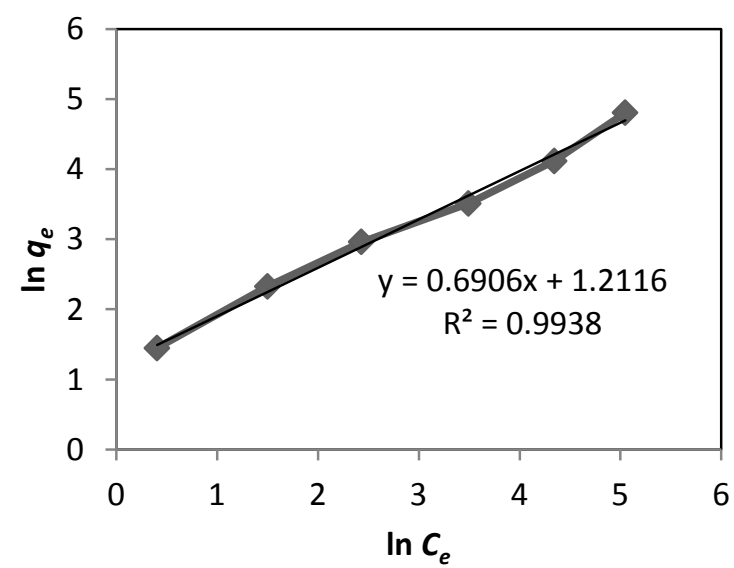

Fig. 9. Freundlich isotherm of adsorption of ARS onto $\mathrm{Bn}$.

Table 1. The parameters of Langmuir and Freundlich isotherm models for the adsorption of ARS onto $\mathrm{Bn}$.

\begin{tabular}{|c|c|c|c|c|c|}
\hline \multicolumn{2}{|c|}{ Langmuir isotherm } & \multicolumn{3}{|c|}{ Freundlich isotherm } \\
\hline$K_{L}$ & $\begin{array}{c}q_{\max }, \\
\mathrm{mgg}^{-1}\end{array}$ & $R^{2}$ & $\begin{array}{c}K_{F}, \\
\mathbf{m g g}^{1} \mathrm{Lmg}^{1) 1 / n}\end{array}$ & $n$ & $R^{2}$ \\
\hline 0.01 & 169.5 & 0.7391 & 3.36 & 1.45 & 0.9938 \\
\hline
\end{tabular}

\subsection{Kinetics Study}

The mechanism of the ARS adsorption onto $\mathrm{Bn}$ is explained using two kinetic models: Lagergren pseudo-first-order [25] and pseudo-second-order [26]. The Lagergren pseudo-first-order model equation:

$\ln \left(q_{e}-q_{t}\right)=\ln q_{e}-k_{1} t$

Pseudo-second-order kinetic equation:

$\frac{t}{q_{t}}=\frac{1}{k_{2} q_{e}{ }^{2}}+\frac{t}{q_{e}}$

Where: $q_{t}$ and $q_{e}$ are the quantities of ARS that are adsorbed per unit mass of $\mathrm{Bn}\left(\mathrm{mg} \mathrm{g}^{-1}\right)$ at time $t$ (min) and that adsorbed at equilibrium, respectively. The values of rate constants $\left(k_{1}, k_{2}\right)$ represent pseudo-first-order constant $\left(\mathrm{min}^{-1}\right)$, and pseudosecond-order rate constant $\left(\mathrm{g} \mathrm{mg}^{-1} \mathrm{~min}\right)$. Figure 10 represents the plot of pseudo- second-order, while the data of $k_{1}, k_{2}$ and $R^{2}$ are demonstrated in Table 2. The ARS adsorption onto $B n$ fitted well with the pseudo-second-order kinetic model and this is indicated by the values of $R^{2}$ as shown in Table 2 .

Table 2. Parameters of the kinetics models for ARS adsorption onto Bn.

\begin{tabular}{|l|l|l|}
\hline Kinetic model & Parameter & Value \\
\hline Pseudo-first-order & $q_{e}\left(\mathrm{mg} \mathrm{g}^{-1}\right)$ & 34.81 \\
& $k_{1}\left(\mathrm{~h}^{-1}\right)$ & 0.0815 \\
& $R^{2}$ & 0.907 \\
Pseudo-second-order & $q_{e}\left(\mathrm{mg} \mathrm{g}^{-1}\right)$ & 42.55 \\
& $k_{2}\left(\mathrm{~h}^{-1}\right)$ & 0.000961 \\
& $R^{2}$ & 0.9526 \\
\hline
\end{tabular}

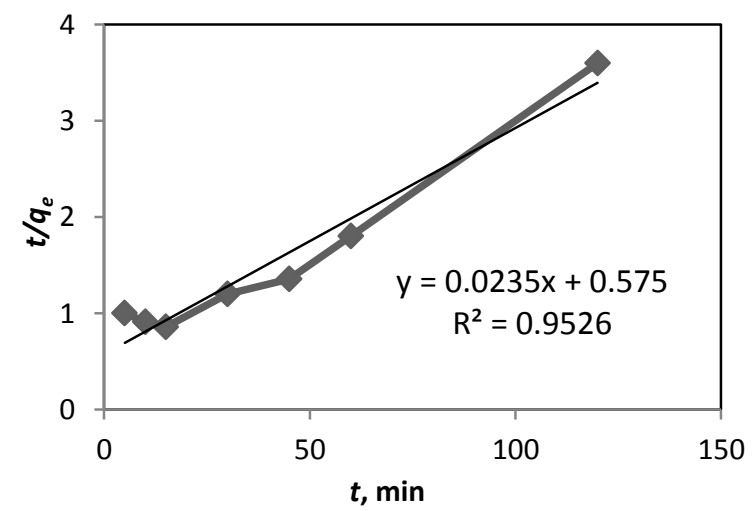

Fig. 10. Pseudo-second-order rate plot for the adsorption of ARS onto $\mathrm{Bn}$. 


\subsection{Thermodynamic Parameters}

Van't Hoff equations [27] are used to calculate the thermodynamic parameters, such as enthalpy $\left(\Delta H^{\circ}\right)$, entropy $\left(\Delta S^{\circ}\right)$ changes and Gibb's free energy change $\left(\Delta G^{\circ}\right)$, and the results are given in Table 3 . The values of $\Delta S^{\circ}$ and $\Delta H^{\circ}$ are determined from the intercept and the slope of the plots (Fig. 11) of $\ln k_{d}$ versus $T^{1}$.

$$
\begin{aligned}
& k_{d}=\frac{q_{e}}{C_{e}} \\
& \ln k_{d}=\frac{\Delta S^{o}}{R}-\frac{\Delta H^{o}}{R T} \\
& \Delta G^{o}=\Delta H^{\circ}-T \Delta S^{\circ}
\end{aligned}
$$

Where: $k_{\mathrm{d}}$ is the distribution coefficient, $q_{\mathrm{e}}$ is the equilibrium concentration of ARS on $\mathrm{Bn}\left(\mathrm{mg} \mathrm{L}^{-1}\right), R$ is gas constant $\left(\mathrm{J} \mathrm{mol}^{-1} \mathrm{~K}^{-1}\right)$ and $T$ is the temperature (K). The negative values of both $\Delta H^{\circ}$ and $\Delta S^{\circ}$ showed that the nature of ARS adsorption is exothermic, and adsorption is accompanying with entropy decrease due to the limit of the mobility of ARS that resulted from binding to the Bn surface [28]. The values of $\Delta G^{\circ}$ are found to be negative at the lower temperature and positive at the higher temperatures, which indicated that the nonspontaneous nature of ARS adsorption onto $\mathrm{Bn}$ at the higher temperatures [29]. The observed increase in $\Delta G^{\circ}$ value with temperature suggested that lowering temperature enhances the process of adsorption of ARS onto Bn.

Table 3. Thermodynamic parameters for the adsorption of ARS onto Bn.

\begin{tabular}{|l|l|l|l|}
\hline Temperature, $\mathrm{K}$ & $\begin{array}{c}\Delta \mathbf{G}^{\circ}, \mathrm{KJ} \\
\mathbf{m o l}^{-1}\end{array}$ & $\begin{array}{c}\Delta \boldsymbol{H}^{\circ}, \mathrm{KJ} \\
\mathbf{m o l}^{-1}\end{array}$ & $\begin{array}{c}\Delta \boldsymbol{S}^{\circ}, \mathbf{J} \\
\mathbf{m o l}^{-1}\end{array}$ \\
\hline 303 & -1.44862 & -63.38676 & -204.419 \\
313 & 0.59554 & & \\
323 & 2.639703 & & \\
333 & 4.683866 & & \\
\hline
\end{tabular}

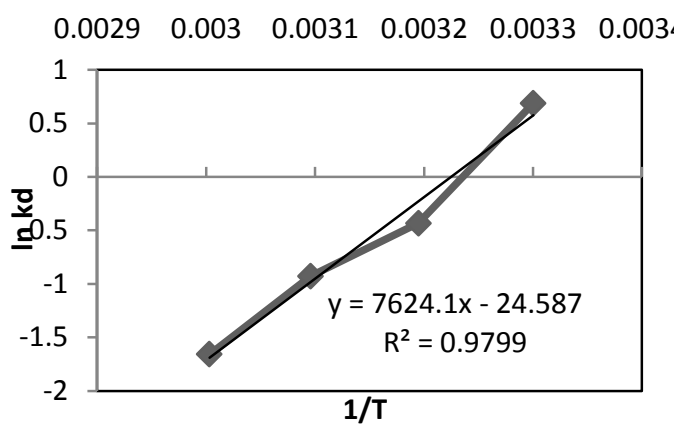

Fig. 11. Plot of In $K_{d}$ versus $1 / T$ for ARS adsorption onto $\mathrm{Bn}$ at different temperatures.

\section{REFERENCES}

Alemdar, A., Güngör, N. and Erim, F.B. 2003. Effect of sodium dodecyl sulfate on flow and electrokinetic properties of $\mathrm{Na}$-activated bentonite dispersions, Mater. Sci. Lett. 27, 317322.

Ansari, R. and Mosayebzadeh, Z. 2010. Removal of Eosin $Y$, an anionic dye, from aqueous solutions using conducting electroactive polymers, Iran. Polym. J. 19, 541-551.

Boyacıa, E., Ahmet, E., Glua, E. and Shahwan, T. 2010. Sorption of $A s(V)$ from waters using chitosan and chitosan-immobilized sodium silicate prior to atomic spectrometric determination, Talanta 80, 1452-1460.

D’Antoni, B.M., Iracà, F. and Romero, M. 2017. Current treatment technologies and practical approaches on textile wastewater Dyes Removal, Panta Rei Srl - Water Solutions, pp. 110.

Gholivand, M.B., Yamini, Y., Dayeni, M. and Shokoohinia, Y. 2015. The influence of the extraction mode on three coumarin compounds yield from Prangos ferulacea (L.) Lindl roots, J. Environ. Chem. Eng. 3, 529-540.

Güngör, N. 2000. Effect of the adsorption of surfactants on the rheology of $\mathrm{Na}$-bentonite slurries, J. Appl. Polym. Sci. 75, 107-110.

Güngör, N., Alemdar, A., Atıcı, O. and Ece, I.Ö. 2001. The Effect of SDS surfactant on the flow and zeta potential of bentonite suspensions, Mater. Lett. 51, 250-254.

Hema, M. and Arivoli, S. 2007. Comparative study on the adsorption kinetics and thermodynamics of dyes onto acid activated low cost carbon, Int. J. Phys. Sci. 2, 10-17.

Ho, Y.S. and McKay, G. 1999. Pseudo-second order model for sorption processes, Water Res.33, 578-584. 
Ho, Y.S. 2004. Citation review of Lagergren kinetic rate equation on adsorption reaction, J. Scientometrics 59, 171-177.

Jain, R., Gupta, V.K. and Sikarwar, S. 2010. Adsorption and desorption studies on hazardous dye Naphthol Yellow S, J. Hazard. Mater. 182, 749-756.

Khare, S.K., Panday, K.K., Srivastava, R.M. and Singh, V.N. 1987. Removal of victoria blue from aqueous solution by fly ash. J. Chem. Techn. Biotechnol. 38, 99-104.

Lagaly, G. 1989. Principles of flow of kaolin and bentonite dispersions, Appl. Clay Sci. 4, 105123.

Leite, I.F., Raposo, C.M.O. and Silva, S.M.L. 2008. Structural characterization of Brazilian and imported bentonitic clays: before and after the process of organophilization for utilization as nanofiller, Cerâmica 54, 303-308.

Luckham, P.F. and Rossi, S. 1999. The colloidal and rheological properties of bentonite suspensions, Adv. Colloid Interface Sci. 82, 43-92.

Madejova, J., Gates, W.P. and Petit, S. 2002. Infrared and Raman spectroscopies of clay Minerals, 8, 107-134.

Malakootian, M., Moosazadeh, M., Yousefi, N. and Fatehizadeh, A. 2011. Fluoride removal from aqueous solution by pumice: Case study on Kuhbonan Water, Afr. J. Environ. Sci. Technol. 5, 299-306.

Mondal, S. 2008. Methods of dye removal from dye house effluent-An overview, Environ. Eng. Sci. 25, 383-396.

Montano, J.G., Torrades, F., Estrada, P., Leonidas, A., Oller, I., Malato, S., Maldonado, M.I. and Peral, J. 2008. Degradation pathways of the commercial reactive azo dye Procion Red $\mathrm{H}$-E7B under solar-assisted photo-Fenton reaction. J. Environ. Sci. Technol. 42, 6663-6670.

Nikita, C.C. and Kini, M.S. 2018. A Review on Adsorption of Cationic Dyes using Activated
Carbon, MATEC Web of Conferences 144, 116.

Ozdemir, F.A., Demirata, B. and Apak, R. 2009. Adsorptive removal of Methylene Blue from simulated dyeing wastewater with melamineformaldehyde-urea resin, J. Appl. Polym. Sci. 112, 3442-3448.

Salehi, R., Dadashian, F. and Ekrami, E. 2018. Acid Dyes Removal from Textile Wastewater Using Waste Cotton Activated Carbon: Kinetic, Isotherm, and thermodynamic studies, Prog. Color Colorants Coat. 11, 9-20.

Sonawane, G.H. and Shrivastava, V.S. 2008. Utilization of bioadsorbent based on zeamaize for removal of water soluble dye: The Kinetic Studies, Ajcer. 1, 19-27.

Wawrzkiewicz, M. and Hubicki, Z. 2010. Equilibrium and kinetic studies on the sorption of acidic dye by macroporous anion exchanger, Biochem. Eng. J. 157, 29-34.

Welzen, J.T.A.M., Stein, H.N., Stevels, J.M. and Siskens, C.A.M. 1981. The influence of surface-active agents on kaolinite, J. Colloid Interface Sci. 81, 455-467.

Yalçin, T., Alemdar, A., Ece, O.l., Güngör, N. and Çoban, F. 2002a. By particle interactions and rheological properties of bentonites + ALS suspensions, Mater. Lett. 53, 211-215.

Yalçin, T., Alemdar, A., Ece, O.I. and Güngör, N. 2002b. The viscosity and zeta potential of bentonite dispersions in presence of anionic surfactants, Mater. Lett. 57, 420-424.

Yang, X., Yang, S.B., Yang, S.T., Hu, J., Tan, X.L. and Wang, X.K. 2001. Effect of pH, ionic strength, foreign ions, fulvic acid and temperature on ${ }^{109} \mathrm{Cd}$ (II) sorption to $\mathrm{y}-\mathrm{Al}_{2} \mathrm{O}_{3}$, Chem. Eng. J. 168, 86-93.

Zhao, D.L., Sheng, G.D., Hu, J., Chen, C.L. and Wang, X.K. 2011. The adsorption of $\mathrm{Pb}$ (II) on $\mathrm{Mg}_{2} \mathrm{Al}$ layered double hydroxide, Chem. Eng. J. 171, 167-174. 


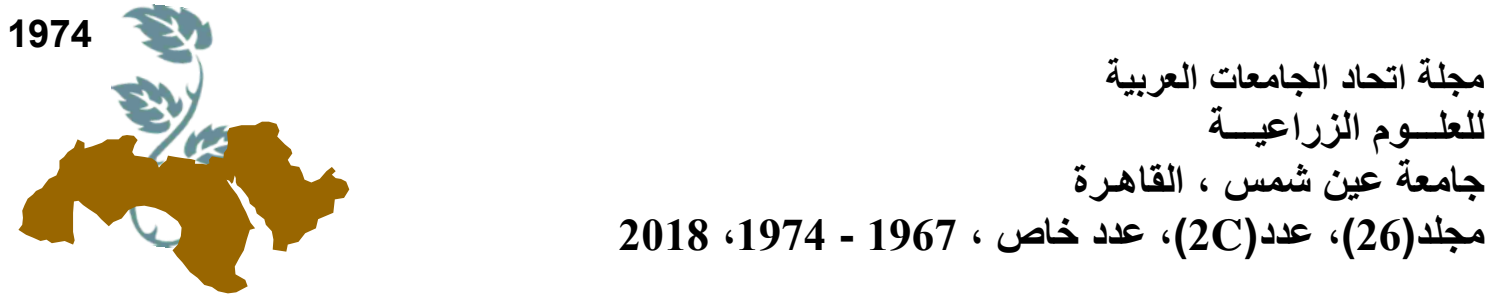
مجلا(26)، عدد (2C)، عدد خاص ، 1967 - 1974، 2018

إزالة أليزارين الأحمر S من المحلول المائي بإستخدام البنتونيت الصوديومى

[145]

ايمان عبد العظيم المنوفي - امنية ابراهيم علي- عبد الحكيم طه قنديل

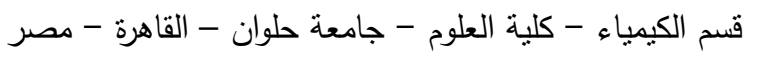

الحموضة، وقت الاتصال، تركيز الصبغة الأولي،

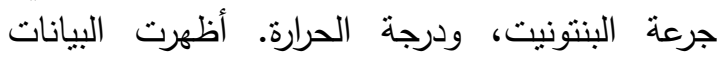

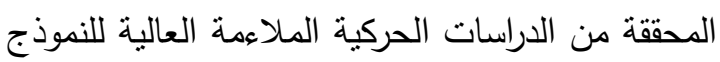

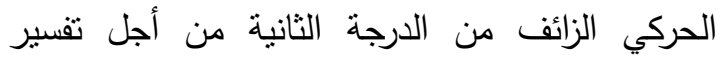

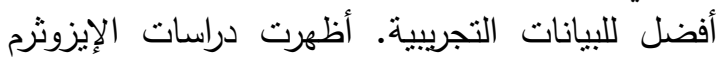

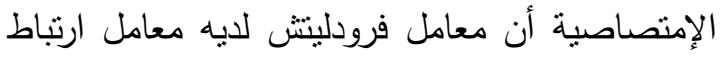

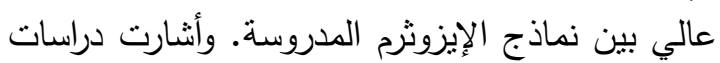

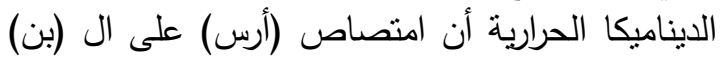
يكون تلقائيا في الطبيعة عند درجات الحرات الحرارة المنخفضة الحنة

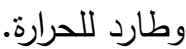

الكلمات الدالة: ازالة، اليزارين الاحمر (أرس)، بنتونيت

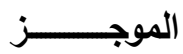

في هذا العمل، نم استخدام البنتونيت الصوديومى الإي

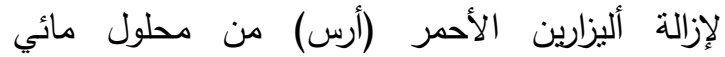

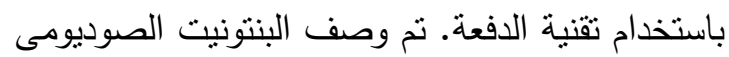

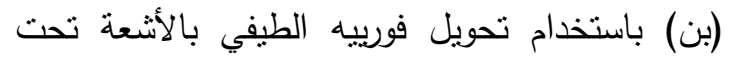

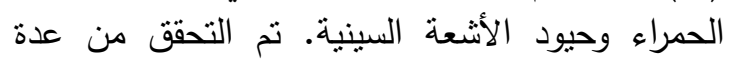

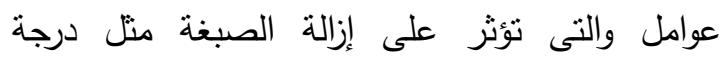





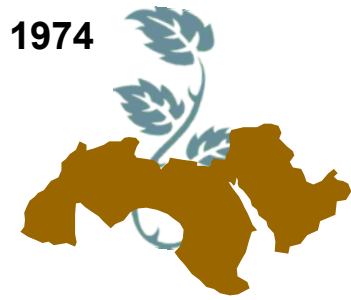

$$
\begin{aligned}
& \text { مجلة اتحاد الجامعات العربية }
\end{aligned}
$$

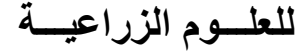

$$
\begin{aligned}
& \text { جامعة عين شمس ، القاهرة }
\end{aligned}
$$

مجلا(26)، عدد (2C)، عدد خاص ، 1967 - 1974، 2018

تحكيم: ا.د عصام عبد العزيز ابراهيم

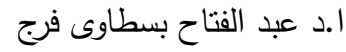

